\title{
Performance, nutrient digestibility and cost evaluation of raw and roasted Afzelia africana seed meal fed finisher broiler chicks.
}

\author{
*Obun, C.O ${ }^{1}$ and Ayanwale, B.A ${ }^{2}$ \\ 'Federal College of Wildlife Management, Department of Animal Production Technology, P.M.B. 268, New \\ Bussa, Niger State. GSM No. 08057019368 \\ ${ }^{2} \mathrm{Federal}$ University of Technology, Minna Faculty of Agric \& Agricultural Technology (SAAT), Department \\ of Animal Production Technology, Minna, Niger State. \\ ${ }^{*}$ Corresponding Author
}

\begin{abstract}
Ninety-nine, 28 day-old broilers were used to investigate the effect of raw and roasted Afzelia Africana seed meal (AASM) on performance, apparent nutrient digestibility and nitrogen retention and cost of broiler production under deep litter system of management for 35 days in the finisher phase. The birds were allotted to three treatments with 33 birds. Each treatment was replicated three times (11 birds per replicate). The data collected were feed intake and body weight gain. Protein efficiency ratio (PER), feed conversion ratio (FCR) and apparent nutrient digestibility were also calculated. The results obtained revealed that chicks fed control (A) diet were significantly $(P<0.05)$ higher in weight gain and feed intake than others. Superior $(P<0.05)$ feed conversion ratio $(F C R)$, protein efficiency ratio (PER), daily feed cost and feed cost per kg weight gain were obtained in roasted dehulled AASM $(C)$ diet when compared to the control and raw AASM diets. The apparent nutrient digestibility of dry matter, crude protein, crude fibre, ash, nitrogen free extract and nitrogen retention of roasted diet compared favourably with that of the control diet. The raw AASM(B) diet depressed performance and nutrient retention values. The cost per $\mathrm{kg}$ diet and cost per live weight gain reduced significantly $(P<P .05)$ in AASM based diets when compared to the control diet. However, the control diet significantly $(P<0.05)$ increased the revenue generated and gross profit when compared to AASM based diets. Based on the results of this study, it is recommended that higher levels of roasted AASM may have some benefits.
\end{abstract}

Keywords: Performance, Nutrient utilization, Afzelia africana seeds, cost evaluation, broiler finisher.

\section{Introduction}

In recent years, there has been increased interest in the utilization of processed soybean and groundnut cake (GNC) as a source of protein supplement for poultry feeding. These ingredients are however not sufficiently available to rely on its use alone as plant protein ingredients in poultry feeds. This limitation coupled with the high costs poses the challenge to search for alternative cheaper and rich plant protein sources to reduce the dwindling poultry industry in the nation resulting from feed shortage.

The search for alternative protein sources of feed ingredients as a partial or complete substitute to soybean and GNC, a conventional costly ingredient in poultry rations has been long and still on-going. This search has attracted a closer look at lesser-known wild legumes. Other unconventional plant protein sources that had 
been used at various times include pigeon pea (Cajanus cajan) (Amaefule and Obioha, 2001), Proposis africana, locust bean (Parkia biglobosa) and Acacia sp (NAS, 1979), Lablab sp.(Okeke 2000).

Afzelia Africana seed (AAS) belongs to the family of leguminosae and sub-family caesalpinocae. It is a perennial tree that thrives along the savannah and drier parts of the forest region (Keay et al., 1964).

The tree grows to a height of $34 \mathrm{~m}$ in the savannah and $13 \mathrm{~m}$ in dry situations, with a girth of up to $3 \mathrm{~m}$. When matured and dried, their pods dehiscent by an explosive mechanism to expose the seeds from November to February. $A$. africana is a quick growing leguminous tree and it is adaptable to a wide variety of soils (Keay et al. 1964). The AAS have been reported (Keay et al., 1964) as a good source of protein for human and animal nutrition. The foliage is looped for fodder and also makes good manure. The use of AAS as a protein source in animal feed is not widely reported in literature. The scarcity and high cost of the conventional protein sources (GNC, SBM) necessitate the need for conducting a research in this relatively unknown AAS. However AAS seeds like other grain legumes contain anti-nutritional factors (Ezeagu et al., 1994; Madubuike el al., 1994; Ajah and Madubuike, 1997; Oduguwa et al. 1999; Oboh and Ekperigin, 2003) such as trypsin inhibitors, tannin, lectin, phytate, oxalate, alkaloid and cyanogens which tend to limit their use as feed sources. Liener (1989) reported effect of some of these anti nutritional factors (ANF) to poultry as follows: tannins interferes with protein and starch digestibility; lectins depressed growth and impose death; trypsin inhibitors depressed growth, pancreatic hypotrophy and interferes with protein digestion; phytate interferes with minerals availability; alkaloids reduce palatability and depressed growth and cyanogens affect respiratory organs. A variety of processing procedures such as soaking, cooking, heating and sprouting of grain legumes have been employed to eliminate the negative effect of $\mathrm{ANF}$ present in tropical raw legumes and other vegetable protein sources (Liener, 1990; Apata and Ologhobo, 1997). To avert this problem, heating (roasting) of AAS was employed to eliminate the ANF. The objectives of this study therefore were to investigate the performance, nutrient digestibility and the cost effective of feeding processed AAS to broiler-finisher chicks.

\section{Materials and Methods}

\section{Experimental site}

This study was carried out in the poultry unit of the Federal University of Technology, Minna, Niger State from September-November, 2005 Source and processing of Afzelia africana seed meal

The Afzelia africana seed meal (AASM) used for the experiment were obtained from Federal College of Wildlife Management reserve estate, New Bussa, Niger State during the dry season months of December- March when the pods split open mechanically.

The seeds were washed and dried to remove residual soil. A portion of the seeds was processed by roasting in a fry pan using local open fire method applied to roasting of groundnut to remove the anti-nutritional factor (ANF).The roasted seeds were ascertained ready when the white endosperm turn cripsy brown as in roasted groundnut. Burning was avoided so as not to destroy some essential amino acids.

The roasted seeds were separated from the sand; lightly pounded with a pestle and mortar and winnowed to remove the chaffs (seed coat). The decorticated seeds were ground in hammer mill and this form roasted dehulled Afzelia africana 
seed meal (RDAASM). A portion of seed was ground raw and referred to as Raw Afzelia africana seed meal (RAASM). The control diet $(0 \%)$ contained no AASM.

\section{Experiment diets}

Three iso-proteinous and iso-caloric finisher diets were formulated such that control diet (A) contained groundnut cake as protein source while diets B and C contained RAASM and RDSAASM respectively, which partially replaced the GNC (Table 2).

\section{Management of the experimental birds \\ Ninety-nine, 4-weeks-old Arbor acre} broiler finishers were raised for this study. The birds were randomly allotted to three dietary treatments of 33 birds each with three replicates of 11 birds each in a completely randomized design (CRD). All routine management and medication were carried out. Feed and clean water were provided ad libitum while the amount of feed given and the left over were recorded on a daily basis. The experimental birds were weighed initially and weekly thereafter until they were 9 weeks old when the experiment was terminated. Weekly feed intake and weight gain were recorded from which feed conversion ratio (FCR) and protein efficiency ratio (PER) were calculated. Daily records of mortality were recorded and expressed as percentage at the termination of the experiment.

\section{Digestibility trial}

At the end of the experimental trial two birds per replicate from each treatment (18 birds) were taken and placed in metabolic cages with facilities for feeding, water supply and collection of droppings. The birds were allowed five days to adjust to the environment before weighed quantity of feed given. Droppings was collected for five days. The droppings were wrapped in aluminium foil and oven dried at $60^{\circ} \mathrm{C}$ for twenty four (24) hours. The droppings were bulked, ground and samples were taken for proximate analysis. The procedure of Vogtmann et al. (1975) was used in calculating the digestibility for fat, crude protein, crude fibre, Ash and NFE.

Apparent digestibility coefficient

$$
=\frac{\text { Nutrient in feed }- \text { Nutrient in feaces }}{\text { Nutrient in feed }} 100
$$

\section{Chemical Analysis}

The proximate composition of the test ingredient (AASM) and experimental diets (Table 1 and 2) were determined by the method of (AOAC, 1990).

\section{Economic of Production}

Money spent on labour for collecting, milling, sun- drying and transporting AASM was recorded. The market cost of each experimental ingredient at the time of the study was used to calculate the total cost of the feed per kg diet, total cost of feed consumed per bird, Gross Profit (G.P) and Revenue (R) were calculated as described by (Faturoti and Lawal, 1986).

\section{Statistical Analysis}

Data obtained were subjected to analysis of variance (ANOVA) by methods of Steel and Torrie (1980). Significant means were separated by Duncan (1955) Multiple Range Test.

\section{Results and Discussion}

The chemical composition of both raw and roasted AASM (Table 1) shows that the RDAASM contain high dry matter $(91.745 \%)$. crude protein (28.64\%), ether extract $(23.40 \%)$ and Nitrogen free extract (38.05\%) but decreased crude fibre $(3.20 \%)$ and ash $(2.90 \%)$ when compared to the respective raw AASM components. 


\section{Afzelia africana seed meal on the performance of broilers}

Table 1: Proximate composition of Afzelia africana seedmeal (\% DM basis)

\begin{tabular}{lcc}
\hline Fraction (\%) & RAASM & RDAASM \\
\hline DM & 89.53 & 91.75 \\
Crude protein & 24.00 & 24.60 \\
Crude fibre & 7.06 & 3.20 \\
Ether Extract & 21.00 & 23.00 \\
Ash & 3.22 & 2.90 \\
NFE & 34.25 & 38.05 \\
\hline
\end{tabular}

RAASM: Raw Afzelia africana seed meal

RDAASM: Roasted dehulled Afzelia africana seed meal

Table 2: Composition of the experimental finisher diets (\%)

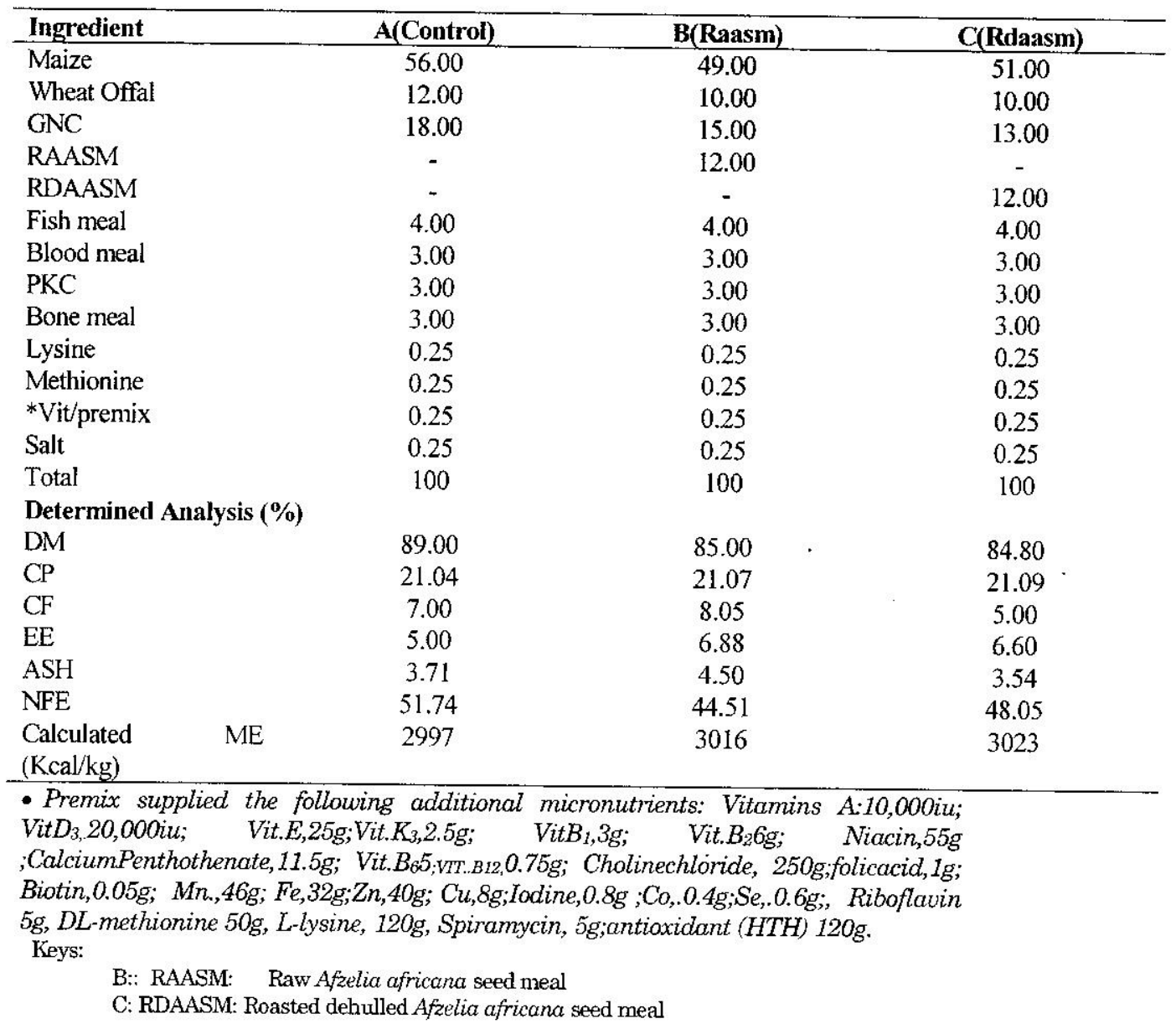


The highest feed intake and body weight gain were recorded by the control diet and were significantly $(P<0.05)$ different from the RAASM and TDAASM diets. The FCR and PER were better in the RDAASM when compared to the others. The daily protein intake was highest in the control diet and was significantly $(P<0.05)$ different from RAASM and RDAASM (Table 3).

The cost benefit analysis of the diets is presented in Table 4. There was reduced cost per $\mathrm{kg}$ diet from $\mathrm{N} 53.00$ in control diet to $\$ 49.60$ in RAASM and $\mathrm{N} 50.00$ in RDAASM diets. The cost of feed consumed/bird reduced from $\mathrm{N} 202.43$ in diet $\mathrm{A}$ to $\mathrm{N} 168.53$ in diet $B$ and $\mathrm{N} 140$ in diet $C$ while the cost per body weight gain were $\$ 80.06$ for diet A, N60.48 for B and $\mathbf{N 6 4 . 3 6}$ for $C$. The highest revenue from birds was in $\operatorname{diet} A(\mathrm{673} .5)$, followed by $\mathrm{C}(\mathrm{N} 577.25)$ and $\mathrm{B}$ ( $\mathrm{N}$ 548.75) while gross profit followed similar trend as Revenue.

Table 3: Performance and cost evaluation of chicks fed experimental finisher diets .

\begin{tabular}{lcccc}
\hline & \multicolumn{4}{c}{ DIETS } \\
\cline { 2 - 5 } \multicolumn{1}{c}{ Treatments } & $\mathrm{A}$ & $\mathrm{B}$ & $\mathrm{C}$ & SEM \\
\hline Number of chicks & 33 & 33 & 33 & \\
Initial body weight (g/bird) & 607.06 & 580.56 & 586.11 & 9.91 \\
Final body weight (g/bird) & 2104.33 & 1800.00 & 1873.33 & 112.64 \\
Body weight gain (g/bird) & $1497.27^{\mathrm{a}}$ & $1219.44^{\mathrm{c}}$ & $1287.22^{\mathrm{b}}$ & 102.52 \\
Daily body weight gain (g/bird) & $42.76^{\mathrm{a}}$ & $34.84^{\mathrm{c}}$ & $36.78^{\mathrm{b}}$ & 2.93 \\
Mean Total feed intake (g/bird) & $3785.12^{\mathrm{a}}$ & $3272.12^{\mathrm{b}}$ & $2792^{\mathrm{c}}$ & 352.23 \\
Mean daily feed intake (g/bird) & $108.15^{\mathrm{a}}$ & $93.49^{\mathrm{b}}$ & $80.00^{\mathrm{c}}$ & 10.00 \\
FCR & 2.53 & 2.70 & 2.18 & 0.19 \\
Daily protein intake (g/bird) & $22.75^{\mathrm{a}}$ & $19.69^{\mathrm{b}}$ & $16.83^{\mathrm{c}}$ & 2.10 \\
PER & $1.82^{\mathrm{b}}$ & $1.77^{\mathrm{c}}$ & $2.19^{\mathrm{a}}$ & 0.16 \\
Mortality (\%) & 0 & 9.4 & 28.6 & - \\
Cost per kg diet (A) & 53.00 & 49.6 & 50.0 & 1.32 \\
Cost of feed intake/bird (A) & $202.43^{\mathrm{a}}$ & $168.53^{\mathrm{b}}$ & $140.00^{\mathrm{c}}$ & 22.17 \\
Cost per kg body weight gain (A) & $80.06^{\mathrm{a}}$ & $60.48^{\mathrm{c}}$ & $64.36^{\mathrm{b}}$ & 7.35 \\
Revenue (N400/kg live weight Gain/birds ( $\mathrm{N}$ ) & $673.53^{\mathrm{b}}$ & $548.75^{\mathrm{c}}$ & $577.25^{\mathrm{c}}$ & 46.37 \\
Gross profit (G.P) (A) & 471.1 & 380.22 & 437.25 & 32.70 \\
\hline
\end{tabular}

$a, b, c$ means on the same row with different superscripts are significantly different $(\mathrm{P}<0.05)$

SEM: Standard error of mean

Table 4: Apparent nutrients digestibility and Nitrogen retention of finisher diets (\% DM basis)

\begin{tabular}{lllll}
\hline Parameters & \multicolumn{3}{c}{ DIETS } \\
\cline { 2 - 5 } & A & B & C & SEM \\
\hline DM & $88.53^{\mathrm{a}}$ & $81.39^{\mathrm{b}}$ & $87.67^{\mathrm{a}}$ & 2.76 \\
CP & $90.38^{\mathrm{a}}$ & $81.69^{\mathrm{b}}$ & $87.89^{\mathrm{a}}$ & 3.17 \\
CF & $85.13^{\mathrm{a}}$ & $73.92^{\mathrm{b}}$ & $89.88^{\mathrm{a}}$ & 4.44 \\
EE & $87.53^{\mathrm{a}}$ & $77.26^{\mathrm{b}}$ & $89.14^{\mathrm{a}}$ & 4.57 \\
Ash & $77.00^{\mathrm{a}}$ & $68.38^{\mathrm{b}}$ & $87.94^{\mathrm{a}}$ & 6.95 \\
Nitrogen Retention & $88.23^{\mathrm{a}}$ & $81.70^{\mathrm{b}}$ & $87.83^{\mathrm{a}}$ & 2.60 \\
\hline a.b,c means on the same row with different superscripts are significantly different $(\mathrm{P}<0.05)$. &
\end{tabular}


The resulits of the appanent metrient digestitbillity and mitrogen reterstion of roasted diet conpquared favourably with control diet showing 3anprowemnent ower the raw ifiet (Table 4 ).

\section{Biscansion}

The increased proximate composition values obtainet in the RDAASM when compared to RAASM may probably be that roasting seemed to comoemirate the mitrogenous connpounds in the beans by removing most of the water molectales thus increasing the dry anatter, crude protein and ether extract contents. While the decreased crude fibre and ash may be due to dehulling of the seeds which reduced the hard seed coat (testa) of the grain and inorganic contents of the seeds.

The high feed intake of birds in the control diets when compared with the RAASM and RDAASM may be due to the low metabolizable energy in the diet. The results obtained therefore supported the observations of Waldroup et al. (1976) and Pesti (1982) that as the level of metabolizable energy in the diet increases or decreases, feed intake changes inversely, although the rate of adjustment is not always sufficient to keep energy intake constant. GNC had been reported to contain $45-49 \% \mathrm{CP}$ (Eyo,2001).It could also be supported by views of A.R.C. (1975), which stated that fast growing chicks eat more food than slow growing ones of the same age. The high feed intake experienced by birds on raw diet than roasted diet could be that most raw feed pass through the alimentary system of the chicks undigested. This observation is in conformity with earlier reports by Sklan et al. (1975) and Rackis (1978) that ingestion of raw oil seed bean meal by chicks did not affect feed intake but caused growth inhibition. The depressed feed intake and body weight gain in AAS based diet may be due to the effect of anti-putritional substances in the seeds. Although the soeds were heated (roasted), it is not impossible that residual protease inhibitors fray still be present in the roasted diet.

Afzelra Africana seeds (AAS) is known to contain some trypsin and chymotrysin inhibitors, lectins, haemagglutins, saponins (Madubuike et al., 1994), alkaloid and other anti-nutritional factors (Oboh and Ekperigin, 2003). These interfere with the biological utilization of the protein and to a lesser extent of available carbohydrate and lipids (Mosley and Griffiths, 1979).

The superior $(\mathrm{P}<0.05)$ FCR and PER exhibited by RDAASM diet may therefore proved that birds on this group optimally utilized the feed protein consumed to maximize production in relation to diets $A$ and $B$. The FCR and PER are parameters that suggest the extent of utilization of diets (Maynard et al., 1979). The poor FCR and PER of raw diet could be that the fibre content of raw diet was beyond a tolerable level, which is put at $5-6.5 \%$ for broilers (Njike and Ndife, 1980).

The mortality of birds fed AASM based diets may probably be due to the cumulative effect of the anti-nutritional factors (ANF). The post mortem (PM) examination revealed that the lungs appeared dark in colour, the heart and the liver were inflated and congested suggesting toxicity. This could be an indication that the heat applied was not appropriate to eliminate the ANFs in the RDAASM. These findings agreed with reports of Udedibie et al. (1994) and Esonu et al. (1997) that most legumes have thermo-labile and thermo stable (tannin and phytate) which needed more that one treatment application. The reason for the high mortality in RDAASM compared to RAAS is not clear. However, it is not impossible that the RDAASM could still retain some residue 
toxic substances which were inactivated dnuring: the heat process.

The improved apparent nutrient digestibility of dry matter, crude protein, crude fibre, ether extract, ash and nitrogen retention (NR) abserved in roasted diet may be due to roasted (decorticated) seeds which improved the digestibility of the protein, lowered the tannin content and reduced the crude fibre and calcium content of the seeds (Salunkhe et al. 1985). The poor apparent nutrient digestibility and nitrogen retention of diet $B$ could be due to high crude fibre content in diet and residual protein inhibitors especially the tannins that reside in the seed coat. Tannins have been known to interfere with protein and starch digestion (Liener, 1989).

The lower cost per $\mathrm{kg}$ of diet observed by birds on RAASM and RDAASM may be due to their local accessibility without high demand. The high cost of feed intake per bird experienced in control diet is in agreement with report (Bogart and Taylor, 1983) that high daily feed intake implies high cost of production. The low cost per live weight gain of RAASM diet could be due to the low feed intake compared with the control and RDAASM. The revenue generated from this study followed similar trend to cost per $\mathrm{kg}$ body weight gain. The better gross profit experienced in control diet may probably be due to high growth rate of birds than raw and roasted diets.

\section{Conclusion}

The feeding trial shows that broilers fed the control diet were significantly $(\mathrm{p}<0.05)$ better in weight gain and feed intake compared to the AASM based diet. The FCR and PER were better in RDAASM compared with the control and RAASM diet. The nutrient digestibility trial of the control and RDAASM were similar and differs significantly $(\mathrm{p}<0.05)$ from the RAASM diet. The cost to benefits: such as the revenue generated and gross profit favoured the control diet but considering the FCR and PER which are factors considered whem makings statement of production and derivable gross margin, RDAASM is favoured. ln conclusion, therefore, I recommend that higher levels of RDAASM may have some economic benefits.

\section{References}

Ajah, P.O. and Madubuike, F.N. 1997: The proximate Composition of some tropical legume seeds grown in two States in Nigeria. Journ. Food Chemistry, Vol. 59 No.3: 361-365.

Amaefule, K.U. and Obioha, F.C. 2001: Performance and nutrient utilization of broiler starters fed diets containing raw and boiled or dehulled pigeon pea seeds. Nig. J. Anim. Prod. 28(1): 31-39.

Apata, D.F. and Ologhobo, A.D. 1997. Trypsin Inhibitor and other anti-nutritional factors in tropical legume seeds. Trop. Sci. 37: 107-114.

A.R.C. 1975: Agricultural Research Council. Nutritional Requirement of Farm Livestock No.1 Poultry Technical reviews and Summary.

A.O.A.C. 1990: Official Method of Analysis $\left(15^{\text {th }}\right.$ ed.) K. Heldrich Association of Official analytical Chemist, Virginia, U.S.A.

Bogart, R. and Taylor, R.E. 1983: Scientific Farm Animal Production, $2^{\text {nd }}$ Edition, Macmillan Publishing Co, New York, U.S.A.

Duncan, D.B. 1955: Multiple Range and Multiple F-test. Biometrics 11:1-42. 
Eyo,A.A. 2001.Chemical composition and amino acid contents of the commonly available feedstuffs used in fish feed in Nigeria.Fish Nutrition feed Techn.,FISON ,Lagos, 14-25pp.

\section{Esonu ,B.O.;Udedibie,A.B.I.and Okpudo,U.F.} 1997. Effect of sprouting snd boiling on the nutritive value of the jack beans ( $C$. ensiformis) for broiler finisher .Appl.Trop.Agric.Vol.2:31$35 \mathrm{pp}$.

Ezeagu, I.E., Metges, C.C, Proll, J., Petzke, K.L. and Akinsoyinu, A.O., 1994: Chemical compositon and nutritive value of some wildgathered Tropical Plant Seeds. Food. Nutr. Bull. 17: 275-278.

Faturoti, E.O. and Lawal, L.A. 1986: Performance of supplementary feeding and organic manuring on the production of Oreochromis niloticus (Tilapia nilotica). Journ. of West African Fisheries, 1:25-32.

Keay, P.W., Onochie, C.P. and Stanfield, D.P. 1964: Nigerian Trees. Vol.I. Federal Dept. of Forestry Research Ibadan, Nigeria.

Liener, I. E., 1989. Antinutritional factors in legume seeds: state of the art. In Recent Advances of Research in Antinutritional Factors in Legume Seeds, [J. Huisman, T.F.B. van der Poel and I.E. Liener, editors]. Pudoc, Wageningen, the Netherlands, 6-13pp.

Liener, I.E. 1990: Naturally occurring toxic factors in animal feedstuffs. In (Wiseman, J. and Cole, D.J.A. Eds) Feedstuff Evaluation, London, Butter worths.120-135pp
Madubuike, F.N., Ojimelukwe, P.C., Ajah, P. U 1994: Proximate Composition, energy content and physicochemical properties of Afzelia africana and Brachystegia eurycoma seeds. Plt. Food. Hum. Nutri. 46:339-344.

Maynard, L.A. Loosii, H.F., and Warner, R.G. 1979. Animal Nutrition. $7^{\text {th }}$ ed. Tarta McGraw Hill publishing New Delhi., 348pp.

Mosley, G. and Griffiths, D.W. 1979: Varietals variation in the anti-nutritive effects of field beans (Vicia faba) when fed to rat. J. Sc. Food Agric. 30: 772-778.

NAS 1979: Tropical Legumes: Resources for the future, National Academy of Science, Washington, D.C. U.S.A. pp.55-58.

Njike, M.C. and Ndife, L.I. 1980: Protein and Energy requirements of broiler chickens in the tropics. Nig. J. Anim. Prod. 7:97-105.

Oboh, G and Ekperigin, M.M. 2003. Nutritional evaluation of some Nigeria wild seeds. Journ. of Food and Hum. Nutr. 7: 204-214.

Oduguwa, B.O., Oduguwa, O.O. and Amore, E.A. 1999. Effect of season on the Anti-nutritional factors in some foliages of some Leguminous trees. In: Proc. of the $26^{\text {th }}$ Ann. Conf. of ASAP. Ilorin, 10-12pp.

Okeke, D.P. 2000: Replacement of soybean meal with Bambara waste in broiler diets. M.Sc. Thesis (Unpublished), Ibadan. University of Ibadan, Ibadan. 
Pecti,G.M. 1982. Characteristics of the response to male broiler chickens to diets with various protein and energy contents during the growing phase .Brit.Poult.Sci.24-41pp

Rackis, C.B. 1978. Digestibility co-efficient of pure Beef, Fat. Acta Agric. Sci. 18: 42-47.

Salunkhe, D.K., Kadam, S.S. and Chavan, J.K. 1985. Post Harvest Biotechnology of food gumes, CRC Press Inc. Boca Raton, Florida U.S.A.,66-130pp

Sklan, D, Hurwetz, S. Budowski, Pand Ascarelli, 1975. Fat digestibility and absorption in chicks fed raw and heat treated soybean meal. J. Nutri. 105:57-63.

Steel, R.G.D. and Torrie, H.H. 1980: Principles and Procedures of Statistics. McGraw Hill Book Company Inc. London.
Udedibie, A.B.I., Esonu,B.O., Obaje,C.N. and Durunna, C. S. 1994.Dry urea treatment prior toasting as a method for improving the nutrients value of the jack beans for broilers . Anim. Feed Sci. Techn.,48:335-345.

Vogtmann, H. Pfirter, P. and Prabuck, A.L. 1975: A new method of determining metabolisability of energy and digestibility of fatty acids in broiler diets. Brit. Poult. Sci. 16:531

Waldroup, P. W., Mitchell, R. J., PAYNE, J.R. and Johnson, Z.B. 1976. Characterization of the response of broiler chickens to diets varying in nutrient density contents .Poult. Sci. 55:130.

(Received 17th July, 2006; Accepted 2nd March 2007). 